\title{
ANALISIS KAS (CASH FLOW) TERHADAP POSISI KEUANGAN USAHA PT TIRTA MEMBRAMO
}

\author{
Wisang Candra Bintari \\ Dosen Universitas Muhammadiyah Sorong \\ Diterima:17 Januari 2017. Disetujui:18 Februari 2017. Dipublikasikan:1 Maret 2017
}

\begin{abstract}
Abstrak
Penelitian ini bertujuan untuk mengetahui pengaruh keuangan yang di peroleh dari laporan keuangan yang di terbitkan oleh perusahaan dapat berpengaruh terhadap kondisi financial perusahaan dan aliran cash flow perusahaan. Perusahaan mempunyai kesempatan untuk ekspansi yang di buktikan dari keuntungan yang di peroleh tiap bulannya. Perusahaan di sarankan untuk menggunakan keuntungan itu untuk investasi aktifa tetap, menambah sumber daya manusia yang kompetensi, serta memperluas lokasi perusahaan. Memperbaiki struktur organisasi untuk jangka panjang. Meningkatkan daerah pemasaran kewilayah wilayah yang berada di luar daerah dan kabupaten sorong. Hasil laporan cash flow perusahaan memberikan dampak untuk posisi keuangan untuk tahun - tahun yang akan dating.
\end{abstract}

\section{Kata Kunci: Cash flow/analisis kas, keuangan, usaha dan dagang}

\section{PENDAHULUAN}

Seiring dengan krisis multi dimensi yang melanda Indonesia, banyak masalah dan penderitaan yang di alami bangsa ini. Yang termasuk menonjol adalah dalam aspek ekonomi, yakni terpuruknya kegiatan ekonomi karena semakin banyak perusahaan yang bangkrut, dan meningkatnya jumlah tenaga kerja yang menganggur. Kebangkrutan suatu perusahaan dapat dilihat dan diukur melalui laporan keuangan. Laporan Keuangan yang diterbitkan oleh perusahaan merupakan salah satu sumber informasi mengenai posisi keuangan perusahaan, kinerja serta perubahan posisi keuangan perusahaan, yang sangat berguna untuk mendukung pengambilan keputusan yang tepat, data keuangan harus dikonversi menjadi informasi yang berguna dalam pengambilan keputusan ekonomis. Hal ini ditempuh dengan cara melakukan analisis pada pemasukan dan pengeluaran dalam kas keuangan perusahaan. Salah satu aspek pentingnya analisis terhadap laporan keuangan dari sebuah perusahaan adalah kegunaannya untuk meramal kelangsungan hidup perusahaan. Prediksi kelangsungan hidup perusahaan sangat penting bagi manajemen dan pemilik perusahaan untuk mengantisipasi kemungkinan adanya potensi kebangkrutan.

Cash flow (aliran kas) merupakan sejumlah uang kas yang keluar dan yang masuk sebagai akibat dari aktivitas perusahaan dengan kata lain adalah aliran kas yang terdiri dari aliran masuk dalam perusahaan dan aliran kas keluar perusahaan serta berapa saldonya setiap periode. Sedangkan Arus kas adalah laporan jumlah antara laba bersih dan depresiasi, di kurangi penambahan dalam piutang usaha dan penambahan dalam persediaan, serta di tambah dengan penambahan dalam piutang usaha yang merupakan siklus atau proses bagi perusahaan untuk menambah jumlah dan 
menggunakan dana tunainya. Laporan arus kas mengklasifikasikan penerimaan kas dan pengeluaran kas berdasarkan aktifitas - aktifitas operasi investasi dan pendanaan. Klasifikasi menurut aktifitas ini akan memberikan informasi yang memungkinkan para pengguna laporan keuangan untuk menilai pengaruh aktivitas tersebut terhadap posisi keuangan serta jumlah kas dan setara kas, baik arus kas masuk maupun arus kas keluar. Arus kas dari aktivitas - aktivitas operasi biasanya disajikan pertama kali, kemudian diikuti oleh arus kas dari aktifitas investasi, dan aktivitas pendanaan. Jumlah arus kas dari aktivitas - aktivitas ini adalah kenaikan bersih atau penurunan bersih kas dalam periode tertentu. Saldo kas pada awal periode di tambah kepada kenaikan atau penurunan bersih kas, dan kemudian di laporkan saldo kas pada akhir periode.

\section{METODOLOGI PENELITIAN}

\section{A. Jenis dan sumber data}

a. Jenis data

Data yang di gunakan dalam penelitian ini adalah data sekunder. Data yang di butuhkan adalah :

a. Aliran kas dari kegiatan operasi yaitu

1. Penambahan kas ( dari kegiatan pruduksi, pengiriman, pembelian, dsb).

2. Pengurangan kas keluar ( dari kegiatan produksi, penjualan,

1. Menghitung arus kas dari kegiatan operasi

Dapat di hitung dengan rumus

$$
\text { Kas masuk - Kas keluar }
$$

2. Menghitung aliran kas dari kegiatan investasi

3. Menghitung aliran kas dari kegiatan pendanaan

Kas masuk Dari kegiatan investasi - Kas keluar untuk

Kas masuk ( pinjaman ) - Kas keluar ( pembayaran pengiriman, pembelian, pemasaran, dsb)

b. Aliran kas dari kegiatan investasi

c. Aliran kas dari kegiatan pendanaan.

Periode dana yang kami ambil mulai bulan agustus 2011 s/d bukan juli 2012.

\section{d. Sumber data}

Sumber data dalam penelitian ini berasal dari perusahaan PT Tirta Mamberamo Sorong.

\section{e. Pengumpulan data}

Data - data diperoleh dengan cara pengamatan langsung di lapangan dan instansi terkait

\section{Data primer}

Berdasarkan obyek yang di teliti, adapun cara pengumpulan data yang di gunakan dengan cara interview yaitu suatu bentuk penelitian/pencarian data dimana untuk mendapatkan data di dalam wawancara pada pihak-pihak yang berkepentingan dengan kegiatan yang berhubungan langsung dengan obyek yang di teliti.

\section{Data sekunder}

Data sekunder yaitu data yang di peroleh melalui kegiatan pustaka seta buku buku / literature - literature yang berhubungan dengan obyek penelitian.

\section{B. Dokumentasi}

Yaitu mempelajari dokumen - dokumen yang berhubungan dengan obyek penelitian.

\section{Teknik analisis dan pengujian data}




\begin{tabular}{|c|c|c|c|c|c|}
\hline \multicolumn{6}{|c|}{$\begin{array}{l}\text { HASIL PENELITIAN DAN PEMBAHASAN } \\
\text { CASH FLOW PT. TIRTA MAMBERAMO } \\
\text { YANG BERAKHIR } 31 \text { Desember } 2011 \\
\text { Harga }\end{array}$} \\
\hline $\begin{array}{c}\text { A. } \\
\text { Produksi/Penjualan }\end{array}$ & & lksi / & $\begin{array}{c}\text { Jumlah Unit / } \\
\text { Bulan }\end{array}$ & \multicolumn{2}{|c|}{ Biaya / Bulan } \\
\hline Gelas & & & 10800 & $\mathrm{Rp}$ & $172,800,000$ \\
\hline Botol & $\mathrm{Rp}$ & 29,000 & 14400 & $\mathrm{Rp}$ & $417,600,000$ \\
\hline Galon & $\mathrm{Rp}$ & 8,000 & 15600 & $\begin{array}{l}\mathrm{Rp} \\
\mathbf{R p}\end{array}$ & $124,800,000$ \\
\hline Jumlah & & & \multicolumn{3}{|c|}{ 715,200,000 } \\
\hline \multicolumn{6}{|l|}{ B. Direct Cost } \\
\hline Upah pokok & & & & $\mathrm{Rp}$ & $21,750,000$ \\
\hline Jamsostek & & & & $\mathrm{Rp}$ & $1,063,575$ \\
\hline Listrik & & & & $\mathrm{Rp}$ & $2,500,000$ \\
\hline THR & & & & $\mathrm{Rp}$ & $1,812,500$ \\
\hline Pelumas & & & & $\mathrm{Rp}$ & 500,000 \\
\hline Bensin & & & & $\mathrm{Rp}$ & $2,000,000$ \\
\hline Bahan Baku & & & & $\mathrm{Rp}$ & $36,000,000$ \\
\hline Filter & & & & $\mathrm{Rp}$ & 200,000 \\
\hline Jumlah & & & & $\mathbf{R p}$ & $65,626,075$ \\
\hline C. Inderect Cost & & & & $\mathbf{R p}$ & $19,687,823$ \\
\hline D. EBITDA & & & & $\mathbf{R p}$ & $629,886,103$ \\
\hline
\end{tabular}

CASH FLOW PT. TIRTA MAMBERAMO

YANG BERAKHIR 31 Desember 2011

A.

Produksi/Penjualan

Gelas

Botol

Galon

Jumlah

B. Direct Cost

Gaji Karyawan

Jamsostek

Listrik

THR

Pelumas

Bensin

Bahan Baku

Filter

Jumlah

C. Inderect Cost
Harga Produksi / Jumlah Unit

\begin{tabular}{lr} 
& \multicolumn{1}{c}{ Unit } \\
$\mathrm{Rp}$ & 16,000 \\
$\mathrm{Rp}$ & 29,000 \\
$\mathrm{Rp}$ & 8,000
\end{tabular}
/ Bulan 10350 13800 14950

\begin{tabular}{cc}
\multicolumn{2}{c}{ Biaya / Bulan } \\
$\mathrm{Rp}$ & $165,600,000$ \\
$\mathrm{Rp}$ & $00,200,000$ \\
$\mathrm{Rp}$ & $119,600,000$ \\
$\mathbf{R p}$ & $\mathbf{6 8 5 , 4 0 0 , 0 0 0}$
\end{tabular}

Rp. $21,750,000$

Rp. $1,063,575$

Rp. $\quad 2,500,000$

Rp. $\quad 1,812,500$

Rp. $\quad 500,000$

Rp. 2,000,000

Rp .34,500,000

Rp. $\quad 200,000$

Rp 64,126,075

Rp. $19,237,823$ 
D. EBITDA

Rp.602,036,103

CASH FLOW PT. TIRTA MAMBERAMO YANG BERAKHIR 31 DESEMBER 2011

\begin{tabular}{|c|c|c|c|c|}
\hline $\begin{array}{c}\text { A. } \\
\text { Produksi/Penjualan } \\
\end{array}$ & $\begin{array}{c}\text { Harga Produksi } \\
\text { / Unit }\end{array}$ & $\begin{array}{c}\text { Jumlah Unit } \\
\text { / Bulan }\end{array}$ & \multicolumn{2}{|c|}{ Biaya / Bulan } \\
\hline Gelas & Rp 16.000 & 11700 & $\mathrm{Rp}$ & $187,200,000$ \\
\hline Botol & Rp 29.000 & 15600 & $\mathrm{Rp}$ & $452,400,000$ \\
\hline Galon & Rp. 8.000 & 16900 & $\mathrm{Rp}$ & $135,200,000$ \\
\hline Jumlah & & & $\mathbf{R p}$ & $774,800,000$ \\
\hline \multicolumn{5}{|l|}{ B. Direct Cost } \\
\hline Gaji Karyawan & & & $\mathrm{Rp}$ & $21,750,000$ \\
\hline Jamsostek & & & $\mathrm{Rp}$ & $1,063,575$ \\
\hline THR & & & $\mathrm{Rp}$ & $1,812,500$ \\
\hline Listrik & & & $\mathrm{Rp}$ & $2,500,000$ \\
\hline Pelumas & & & $\mathrm{Rp}$ & 500,000 \\
\hline Bensin & & & $\mathrm{Rp}$ & $2,000,000$ \\
\hline Bahan Baku & & & $\mathrm{Rp}$ & $39,000,000$ \\
\hline Filter & & & $\mathrm{Rp}$ & 200,000 \\
\hline Jumlah & & & $\mathbf{R p}$ & $68,626,075$ \\
\hline C. Inderect Cost & & & $\mathbf{R p}$ & $20,587,823$ \\
\hline D. EBITDA & & & $\mathbf{R p}$ & $685,586,103$ \\
\hline
\end{tabular}

\begin{tabular}{|c|c|c|c|c|}
\hline CASH FLOW PT. & \multicolumn{4}{|c|}{$\begin{array}{l}\text { TIRTA MAMBERAMO YANG BERAKHIR } 31 \\
\text { OKTOBER } 2011\end{array}$} \\
\hline $\begin{array}{c}\text { A. } \\
\text { Produksi/Penjualan }\end{array}$ & $\begin{array}{l}\text { Harga Produksi } \\
\text { / Unit }\end{array}$ & $\begin{array}{l}\text { Jumlah Unit } \\
\text { / Bulan }\end{array}$ & & ya / Bulan \\
\hline Gelas & Rp 16.000 & 11250 & $\mathrm{Rp}$ & $180,000,000$ \\
\hline Botol & $\operatorname{Rp} 29.000$ & 15000 & $\mathrm{Rp}$ & $435,000,000$ \\
\hline Galon & Rp. 8.000 & 16250 & $\mathrm{Rp}$ & $130,000,000$ \\
\hline Jumlah & & & $\mathbf{R p}$ & $745,000,000$ \\
\hline \multicolumn{5}{|l|}{ B. Direct Cost } \\
\hline Gaji Karyawan & & & $\mathrm{Rp}$ & $21,750,000$ \\
\hline Jamsostek & & & $\mathrm{Rp}$ & $1,063,575$ \\
\hline THR & & & $\mathrm{Rp}$ & $2,500,000$ \\
\hline Listrik & & & $\mathrm{Rp}$ & $1,812,500$ \\
\hline Pelumas & & & $\mathrm{Rp}$ & 500,000 \\
\hline Bensin & & & $\mathrm{Rp}$ & $2,000,000$ \\
\hline Bahan Baku & & & $\mathrm{Rp}$ & $37,500,000$ \\
\hline Filter & & & $\mathrm{Rp}$ & 200,000 \\
\hline Jumlah & & & $\mathbf{R p}$ & $67,126,075$ \\
\hline C. Inderect Cost & & & $\mathbf{R p}$ & $20,137,823$ \\
\hline D. EBITDA & & & $\mathbf{R p}$ & $657,736,103$ \\
\hline
\end{tabular}




\begin{tabular}{|c|c|c|c|}
\hline \multirow{2}{*}{$\begin{array}{c}\text { CASH FLOW PT. } \\
\begin{array}{c}\text { A. Produksi/ } \\
\text { Penjualan }\end{array} \\
\end{array}$} & \multicolumn{3}{|c|}{$\begin{array}{l}\text { TIRTA MAMBERAMO YANG BERAKHIR } 31 \\
\text { NOVEMBER } 2011\end{array}$} \\
\hline & $\begin{array}{l}\text { Harga Produksi } \\
\text { / Unit }\end{array}$ & $\begin{array}{l}\text { Jumlah Unit } \\
\text { / Bulan }\end{array}$ & Biaya / Bulan \\
\hline Gelas & Rp 16.000 & 11700 & $\operatorname{Rp} 187,200,000$ \\
\hline Botol & Rp 29.000 & 15600 & $\operatorname{Rp} 452,400,000$ \\
\hline Galon & Rp. 8.000 & 16900 & $\operatorname{Rp} 135,200,000$ \\
\hline Jumlah & & & Rp 774,800,000 \\
\hline \multicolumn{4}{|l|}{ B. Direct Cost } \\
\hline Gaji Karyawan & & & $\operatorname{Rp} 21,750,000$ \\
\hline Jamsostek & & & $\mathrm{Rp} \quad 1,063,575$ \\
\hline THR & & & $\mathrm{Rp} \quad 2,500,000$ \\
\hline Listrik & & & $1,812,500$ \\
\hline Pelumas & & & 500,000 \\
\hline Bensin & & & $2,000,000$ \\
\hline Bahan Baku & & & $\operatorname{Rp} 39,000,000$ \\
\hline Filter & & & $\mathrm{Rp} \quad 200,000$ \\
\hline Jumlah & & & Rp $\quad 68,626,075$ \\
\hline C. Inderect Cost & & & $\begin{array}{ll}\mathbf{R p} & \mathbf{2 0 , 5 8 7 , 8 2 3}\end{array}$ \\
\hline D. EBITDA & & & Rp 685,586,103 \\
\hline
\end{tabular}

\begin{tabular}{|c|c|c|c|c|}
\hline CASH FLOW PT. & \multicolumn{4}{|c|}{$\begin{array}{l}\text { TIRTA MAMBERAMO YANG BERAKHIR } \\
\text { JANUARI } 2012\end{array}$} \\
\hline $\begin{array}{c}\text { A. } \\
\text { Produksi/Penjualan }\end{array}$ & $\begin{array}{c}\text { Harga Produksi } \\
\text { / Unit }\end{array}$ & $\begin{array}{c}\text { Jumlah Unit } \\
\text { / Bulan }\end{array}$ & & iaya / Bulan \\
\hline Gelas & $\operatorname{Rp} 16.000$ & 11250 & & $180,000,000$ \\
\hline Botol & Rp 29.000 & 15000 & $\mathrm{Rp}$ & $435,000,000$ \\
\hline Galon & Rp. 8.000 & 16250 & $\mathrm{Rp}$ & $130,000,000$ \\
\hline Jumlah & & & $\mathbf{R p}$ & $745,000,000$ \\
\hline \multicolumn{5}{|l|}{ B. Direct Cost } \\
\hline Gaji Karyawan & & & & $21,750,000$ \\
\hline Jamsostek & & & $\mathrm{Rp}$ & $1,063,575$ \\
\hline THR & & & $\mathrm{Rp}$ & $2,500,000$ \\
\hline Listrik & & & $\mathrm{Rp}$ & $1,812,500$ \\
\hline Pelumas & & & $\mathrm{Rp}$ & 500,000 \\
\hline Bensin & & & $\mathrm{Rp}$ & $2,000,000$ \\
\hline Bahan Baku & & & $\mathrm{Rp}$ & $37,500,000$ \\
\hline Filter & & & $\mathrm{Rp}$ & 200,000 \\
\hline Jumlah & & & $\mathbf{R p}$ & $67,126,075$ \\
\hline C. Inderect Cost & & & $\mathbf{R p}$ & $20,137,823$ \\
\hline D. EBITDA & & & $\mathbf{R p}$ & $657,736,103$ \\
\hline
\end{tabular}




\begin{tabular}{ccccc}
\hline CASH FLOW PT. & \multicolumn{3}{c}{$\begin{array}{c}\text { TIRTA MAMBERAMO YANG BERAKHIR 29 } \\
\text { FEBRUARI 2012 }\end{array}$} \\
\hline $\begin{array}{c}\text { A. Produksi/ } \\
\text { Penjualan }\end{array}$ & $\begin{array}{c}\text { Harga Produksi } \\
\text { / Unit }\end{array}$ & $\begin{array}{c}\text { Jumlah Unit } \\
\text { / Bulan }\end{array}$ & \multicolumn{2}{c}{ Biaya / Bulan } \\
\hline Gelas & Rp 16.000 & 10350 & $\mathrm{Rp}$ & $165,600,000$ \\
Botol & $\mathrm{Rp} 29.000$ & 13800 & $\mathrm{Rp}$ & $400,200,000$ \\
Galon & Rp. 8.000 & 14950 & $\mathrm{Rp}$ & $119,600,000$ \\
\hline Jumlah & & & Rp & $\mathbf{6 8 5 , 4 0 0 , 0 0 0}$ \\
\hline B. Direct Cost & & & $\mathrm{Rp}$ & $21,750,000$ \\
Gaji Karyawan & & & $\mathrm{Rp}$ & $1,063,575$ \\
Jamsostek & & & $\mathrm{Rp}$ & $2,500,000$ \\
THR & & & $\mathrm{Rp}$ & $1,812,500$ \\
Listrik & & $\mathrm{Rp}$ & 500,000 \\
Pelumas & & $\mathrm{Rp}$ & $2,000,000$ \\
Bensin & & $\mathrm{Rp}$ & $34,500,000$ \\
Bahan Baku & & $\mathrm{Rp}$ & 200,000 \\
Filter & & $\mathbf{R p}$ & $\mathbf{6 4 , 1 2 6 , 0 7 5}$ \\
\hline Jumlah & & $\mathbf{R p}$ & $\mathbf{1 9 , 2 3 7 , 8 2 3}$ \\
C. Inderect Cost & & $\mathbf{6 0 2 , 0 3 6 , 1 0 3}$ \\
D. EBITDA &
\end{tabular}

\begin{tabular}{|c|c|c|c|}
\hline CASH FLOW PT. & \multicolumn{3}{|c|}{$\begin{array}{l}\text { TIRTA MAMBERAMO YANG BERAKHIR } 31 \\
\text { MARET } 2012\end{array}$} \\
\hline $\begin{array}{l}\text { A. Produksi/ } \\
\text { Penjualan }\end{array}$ & $\begin{array}{l}\text { Harga Produksi } \\
\text { / Unit }\end{array}$ & $\begin{array}{l}\text { Jumlah Unit } \\
\text { / Bulan }\end{array}$ & Biaya / Bulan \\
\hline Gelas & Rp 16.000 & 11700 & RP.187.200.000 \\
\hline Botol & $\operatorname{Rp} 29.000$ & 15600 & RP.452.400.000 \\
\hline Galon & Rp. 8.000 & 16900 & $\operatorname{Rp} 135,200,000$ \\
\hline Jumlah & & & Rp 774,800,000 \\
\hline \multicolumn{4}{|l|}{ B. Direct Cost } \\
\hline Gaji Karyawan & & & $\mathrm{Rp} \quad 21,750,000$ \\
\hline Jamsostek & & & $1,063,575$ \\
\hline THR & & & $1,812,500$ \\
\hline Listrik & & & $2,500,000$ \\
\hline Pelumas & & & 500,000 \\
\hline Bensin & & & $2,000,000$ \\
\hline Bahan Baku & & & $\mathrm{Rp} \quad 39,000,000$ \\
\hline Filter & & & 200,000 \\
\hline Jumlah & & & Rp $\quad 68,626,075$ \\
\hline C. Inderect Cost & & & Rp $20,587,823$ \\
\hline D. EBITDA & & & Rp $685,586,103$ \\
\hline
\end{tabular}




\begin{tabular}{|c|c|c|c|}
\hline \multirow{2}{*}{$\begin{array}{c}\text { CASH FLOW PT. } \\
\begin{array}{c}\text { A. Produksi/ } \\
\text { Penjualan }\end{array} \\
\end{array}$} & \multicolumn{3}{|c|}{$\begin{array}{l}\text { TIRTA MAMBERAMO YANG BERAKHIR } 30 \\
\text { APRIL } 2012\end{array}$} \\
\hline & $\begin{array}{l}\text { Harga Produksi } \\
\text { / Unit }\end{array}$ & $\begin{array}{l}\text { Jumlah Unit } \\
\text { / Bulan }\end{array}$ & Biaya / Bulan \\
\hline Gelas & Rp 16.000 & 11700 & Rp $172,800,000$ \\
\hline Botol & Rp 29.000 & 15600 & Rp $417,600,000$ \\
\hline Galon & Rp. 8.000 & 16900 & Rp $124,800,000$ \\
\hline Jumlah & & & Rp $715,200,000$ \\
\hline \multicolumn{4}{|l|}{ B. Direct Cost } \\
\hline Gaji Karyawan & & & Rp $\quad 21,750,000$ \\
\hline Jamsostek & & & $1,063,575$ \\
\hline THR & & & $2,500,000$ \\
\hline Listrik & & & $1,812,500$ \\
\hline Pelumas & & & 500,000 \\
\hline Bensin & & & $2,000,000$ \\
\hline Bahan Baku & & & $\operatorname{Rp} \quad 36,000,000$ \\
\hline Filter & & & $\mathrm{Rp} \quad 200,000$ \\
\hline Jumlah & & & Rp $\quad 65,626,075$ \\
\hline C. Inderect Cost & & & Rp $19,687,823$ \\
\hline D. EBITDA & & & $\operatorname{Rp} \quad 629,886,103$ \\
\hline
\end{tabular}

\begin{tabular}{|c|c|c|c|c|}
\hline CASH FLOW PT. & \multicolumn{4}{|c|}{$\begin{array}{l}\text { TIRTA MAMBERAMO YANG BERAKHIR } 30 \\
\text { APRIL } 2012\end{array}$} \\
\hline $\begin{array}{c}\text { A. } \\
\text { Produksi/Penjualan }\end{array}$ & $\begin{array}{l}\text { Harga Produksi } \\
\text { / Unit }\end{array}$ & $\begin{array}{l}\text { Jumlah Unit } \\
\text { / Bulan }\end{array}$ & \multicolumn{2}{|c|}{ Biaya / Bulan } \\
\hline Gelas & Rp 16.000 & 11250 & & $172,800,000$ \\
\hline Botol & Rp 29.000 & 15000 & $\mathrm{Rp}$ & $417,600,000$ \\
\hline Galon & Rp. 8.000 & 16250 & $\mathrm{Rp}$ & $124,800,000$ \\
\hline Jumlah & & & $\mathbf{R p}$ & $715,200,000$ \\
\hline \multicolumn{5}{|l|}{ B. Direct Cost } \\
\hline Gaji Karyawan & & & & $21,750,000$ \\
\hline Jamsostek & & & $\mathrm{Rp}$ & $1,063,575$ \\
\hline THR & & & $\mathrm{Rp}$ & $2,500,000$ \\
\hline Listrik & & & $\mathrm{Rp}$ & $1,812,500$ \\
\hline Pelumas & & & $\mathrm{Rp}$ & 500,000 \\
\hline Bensin & & & $\mathrm{Rp}$ & $2,000,000$ \\
\hline Bahan Baku & & & $\mathrm{Rp}$ & $36,000,000$ \\
\hline Filter & & & $\mathrm{Rp}$ & 200,000 \\
\hline Jumlah & & & $\mathbf{R p}$ & $65,626,075$ \\
\hline C. Inderect Cost & & & $\mathbf{R p}$ & $19,687,823$ \\
\hline D. EBITDA & & & $\mathbf{R p}$ & $629,886,103$ \\
\hline
\end{tabular}




\begin{tabular}{|c|c|c|c|}
\hline \multirow{2}{*}{$\begin{array}{c}\text { CASH FLOW PT. } \\
\begin{array}{c}\text { A. Produksi/ } \\
\text { Penjualan }\end{array} \\
\end{array}$} & \multicolumn{3}{|c|}{$\begin{array}{l}\text { TIRTA MAMBERAMO YANG BERAKHIR } 31 \\
\text { MEI } 2012\end{array}$} \\
\hline & $\begin{array}{l}\text { Harga Produksi } \\
\text { / Unit }\end{array}$ & $\begin{array}{l}\text { Jumlah Unit } \\
\text { / Bulan }\end{array}$ & Biaya / Bulan \\
\hline Gelas & Rp 16.000 & 10350 & Rp $165,600,000$ \\
\hline Botol & Rp 29.000 & 13800 & Rp $400,200,000$ \\
\hline Galon & Rp. 8.000 & 14950 & Rp $119,600,000$ \\
\hline Jumlah & & & $\begin{array}{ll}R p & 685,400,000 \\
\end{array}$ \\
\hline \multicolumn{4}{|l|}{ B. Direct Cost } \\
\hline Gaji Karyawan & & & Rp $\quad 21,750,000$ \\
\hline Jamsostek & & & $1,063,575$ \\
\hline THR & & & $2,500,000$ \\
\hline Listrik & & & $1,812,500$ \\
\hline Pelumas & & & 500,000 \\
\hline Bensin & & & $2,000,000$ \\
\hline Bahan Baku & & & $\operatorname{Rp} \quad 34,500,000$ \\
\hline Filter & & & 200,000 \\
\hline Jumlah & & & Rp $\quad 64,126,075$ \\
\hline C. Inderect Cost & & & Rp $19,237,823$ \\
\hline D. EBITDA & & & $\operatorname{Rp} \quad 602,036,103$ \\
\hline
\end{tabular}

\begin{tabular}{|c|c|c|c|c|}
\hline CASH FLOW PT. & \multicolumn{4}{|c|}{$\begin{array}{l}\text { TIRTA MAMBERAMO YANG BERAKHIR } 30 \\
\text { JUNI } 2012\end{array}$} \\
\hline $\begin{array}{l}\text { A. Produksi/ } \\
\text { Penjualan }\end{array}$ & $\begin{array}{l}\text { Harga Produksi } \\
\text { / Unit }\end{array}$ & $\begin{array}{l}\text { Jumlah Unit } \\
\text { / Bulan }\end{array}$ & & iaya / Bulan \\
\hline Gelas & Rp 16.000 & 11250 & $\mathrm{Rp}$ & $180,000,000$ \\
\hline Botol & Rp 29.000 & 15000 & $\mathrm{Rp}$ & $435,000,000$ \\
\hline Galon & Rp. 8.000 & 16250 & $\mathrm{Rp}$ & $130,000,000$ \\
\hline Jumlah & & & $\mathbf{R p}$ & $745,000,000$ \\
\hline \multicolumn{5}{|l|}{ B. Direct Cost } \\
\hline Gaji Karyawan & & & & $21,750,000$ \\
\hline Jamsostek & & & $\mathrm{Rp}$ & $1,063,575$ \\
\hline THR & & & $\mathrm{Rp}$ & $2,500,000$ \\
\hline Listrik & & & $\mathrm{Rp}$ & $1,812,500$ \\
\hline Pelumas & & & $\mathrm{Rp}$ & 500,000 \\
\hline Bensin & & & $\mathrm{Rp}$ & $2,000,000$ \\
\hline Bahan Baku & & & $\mathrm{Rp}$ & $37,500,000$ \\
\hline Filter & & & $\mathrm{Rp}$ & 200,000 \\
\hline Jumlah & & & $\mathbf{R p}$ & $67,126,075$ \\
\hline C. Inderect Cost & & & $\mathbf{R p}$ & $20,137,823$ \\
\hline EBITDA & & & $\mathbf{R p}$ & $657,736,103$ \\
\hline
\end{tabular}




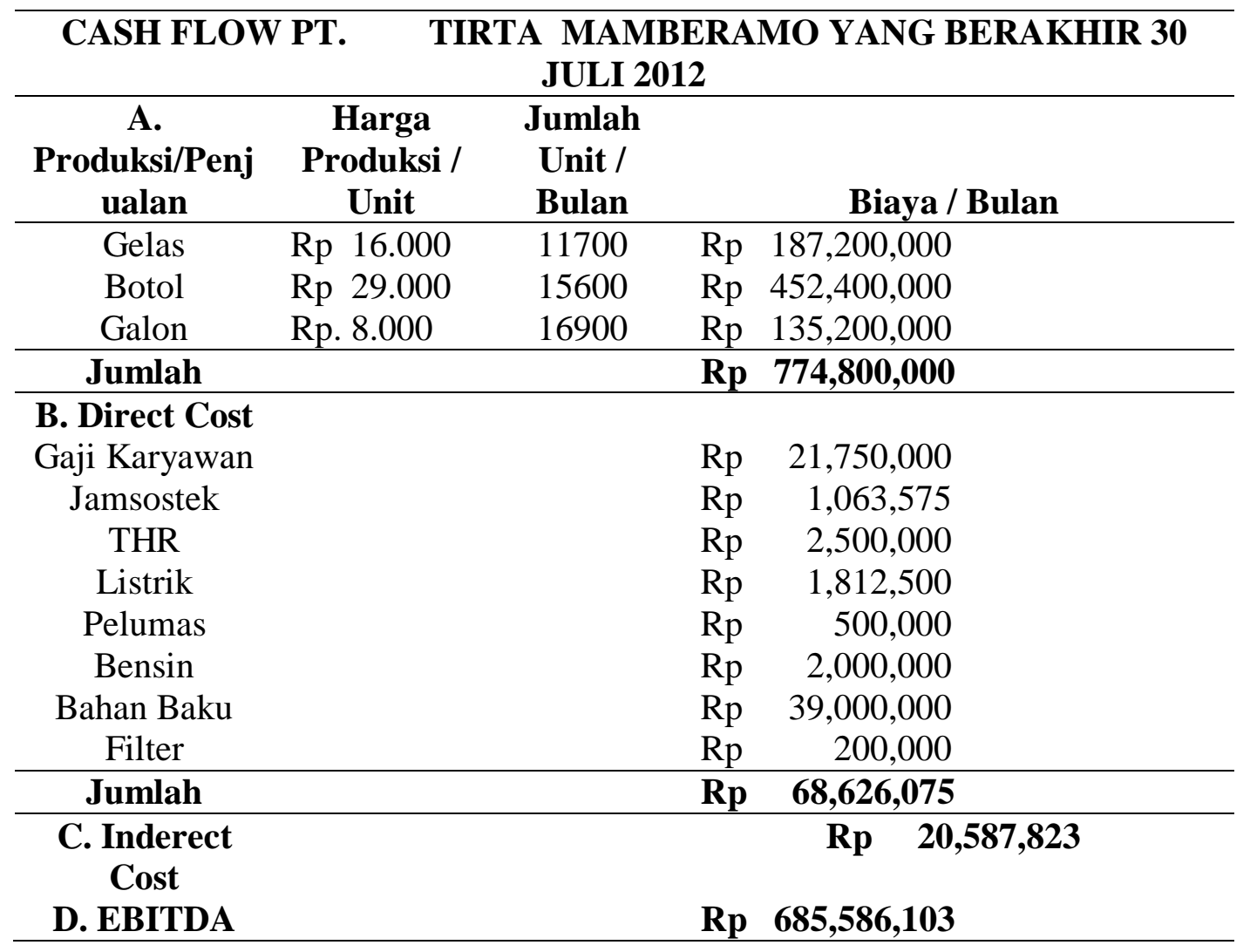

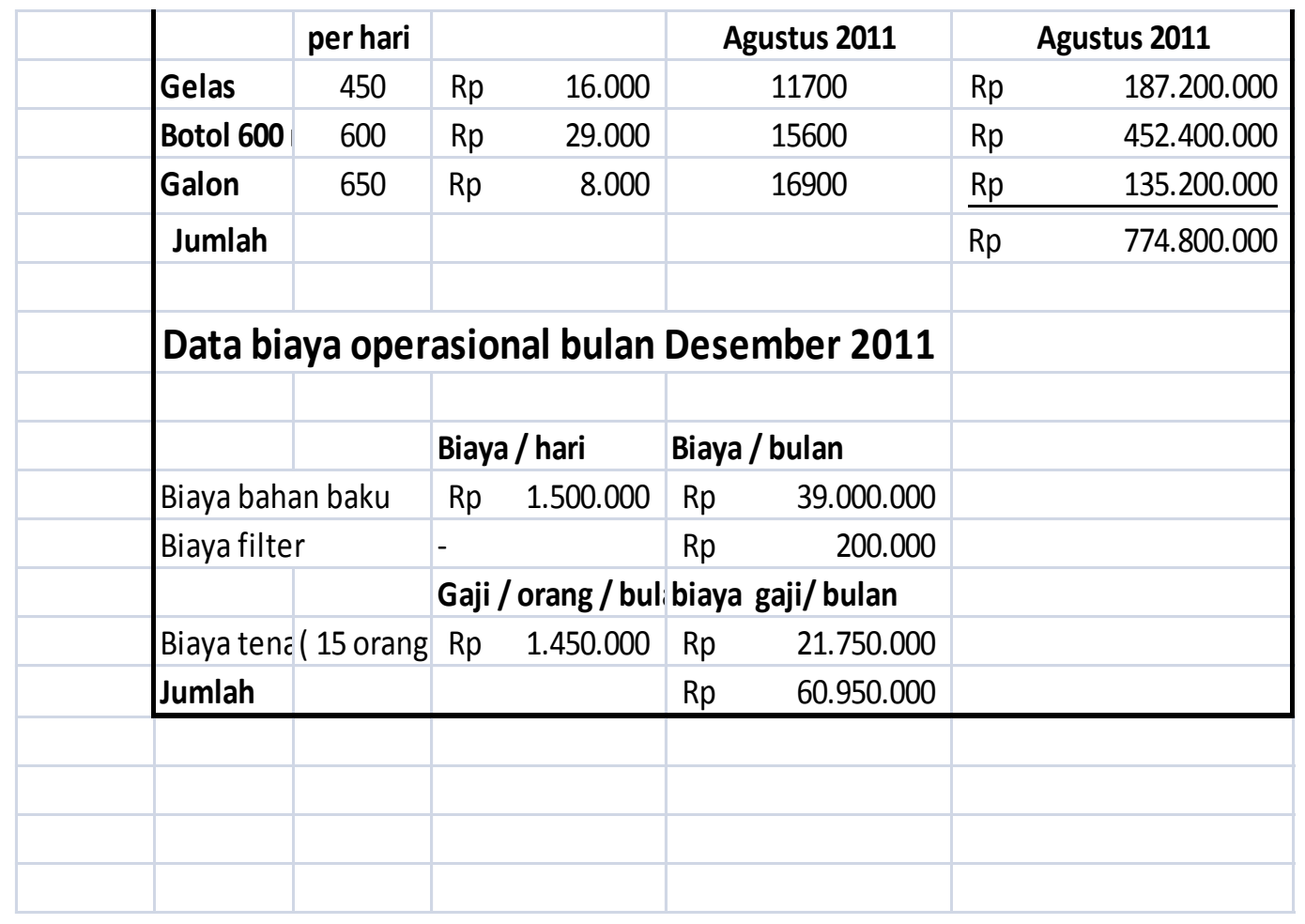




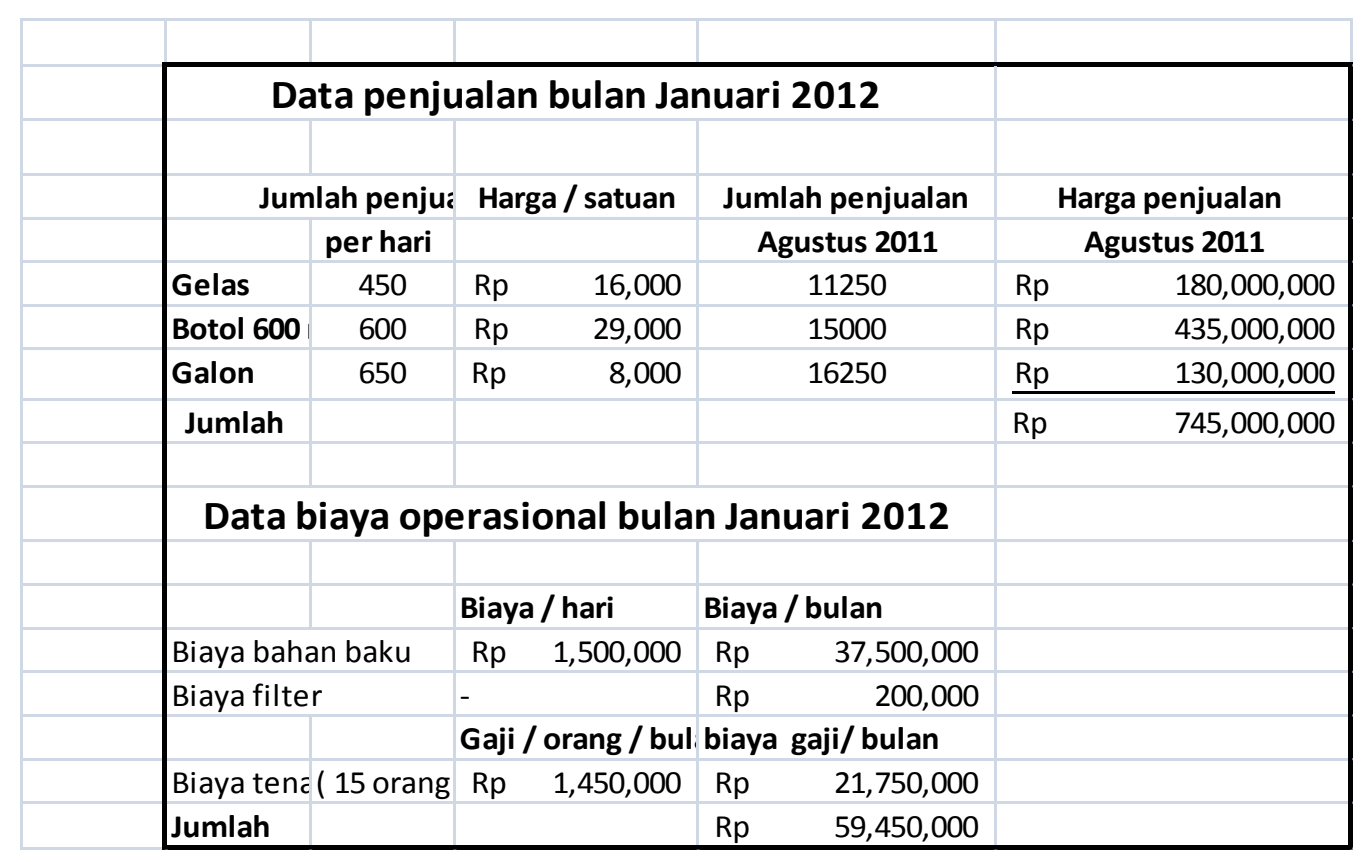

\begin{tabular}{|c|c|c|c|c|c|c|c|}
\hline & & \multicolumn{6}{|c|}{ Data penjualan bulan Februari 2012} \\
\hline \multicolumn{2}{|c|}{ Jumlah penjus } & \multicolumn{2}{|c|}{ Harga / satuan } & \multicolumn{2}{|c|}{ Jumlah penjualan } & \multicolumn{2}{|c|}{ Harga penjualan } \\
\hline & per hari & & & & Igustus 2011 & \multicolumn{2}{|c|}{ Agustus 2011} \\
\hline Gelas & 450 & $\mathrm{Rp}$ & 16,000 & & 10800 & $\mathrm{Rp}$ & $172,800,000$ \\
\hline Botol 600 & 600 & $\mathrm{Rp}$ & 29,000 & & 14400 & $\mathrm{Rp}$ & $417,600,000$ \\
\hline Galon & 650 & $\mathrm{Rp}$ & 8,000 & & 15600 & $\mathrm{Rp}$ & $124,800,000$ \\
\hline Jumlah & & & & & & $\overline{\mathrm{Rp}}$ & $715,200,000$ \\
\hline & & \multicolumn{6}{|c|}{ Data biaya operasional bulan Februari 2012} \\
\hline & & & & & & & \\
\hline & & \multicolumn{2}{|c|}{ Biaya / hari } & \multicolumn{2}{|c|}{ Biaya / bulan } & & \\
\hline \multicolumn{2}{|c|}{ Biaya bahan baku } & & $1,500,000$ & & $36,000,000$ & & \\
\hline \multicolumn{2}{|c|}{ Biaya filter } & - & & & 200,000 & & \\
\hline & & \multicolumn{4}{|c|}{ Gaji / orang / bula biaya gaji/ bulan } & & \\
\hline Biaya ten & ( 15 orang & $\mathrm{Rp}$ & $1,450,000$ & $\mathrm{Rp}$ & $21,750,000$ & & \\
\hline Jumlah & & & & $\mathrm{Rp}$ & $57,950,000$ & & \\
\hline
\end{tabular}




\section{Jurnal Noken 2 (2)1-14 2017}

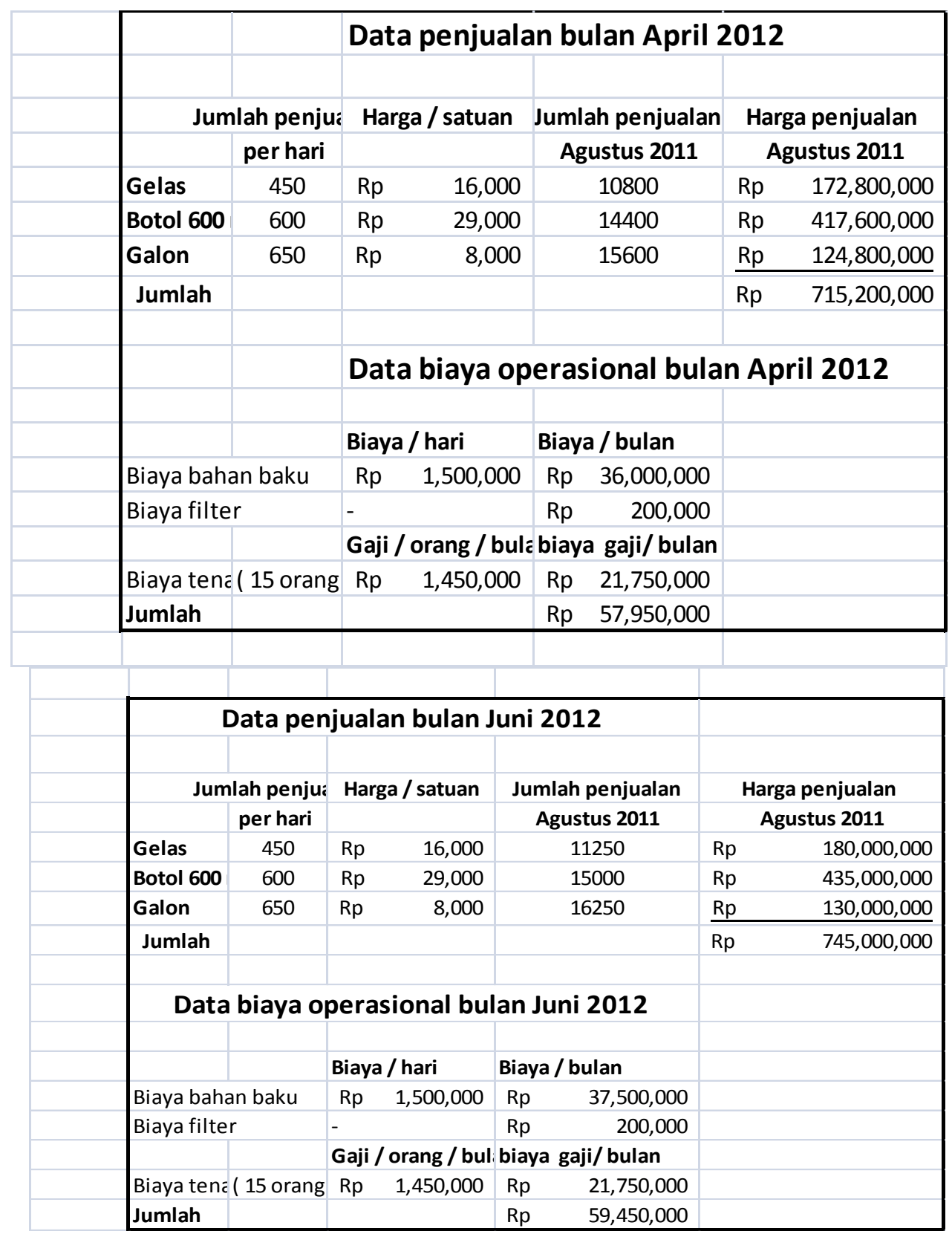




\begin{tabular}{|c|c|c|c|c|c|c|c|}
\hline \multicolumn{6}{|c|}{ Data penjualan bulan Juli 2012} & & \\
\hline \multicolumn{2}{|c|}{ Jumlah penju: } & \multicolumn{2}{|c|}{ Harga / satuan } & \multicolumn{2}{|c|}{ Jumlah penjualan } & \multirow{2}{*}{\multicolumn{2}{|c|}{$\begin{array}{c}\text { Harga penjualan } \\
\text { Agustus } 2011\end{array}$}} \\
\hline & per hari & & & \multicolumn{2}{|c|}{ Agustus 2011} & & \\
\hline Gelas & 450 & $\mathrm{Rp}$ & 16,000 & & 11700 & $\mathrm{Rp}$ & $187,200,000$ \\
\hline Botol 600 & 600 & $\mathrm{Rp}$ & 29,000 & & 15600 & $\mathrm{Rp}$ & $452,400,000$ \\
\hline Galon & 650 & $\mathrm{Rp}$ & 8,000 & & 16900 & $\underline{\mathrm{Rp}}$ & $135,200,000$ \\
\hline Jumlah & & & & & & $\mathrm{Rp}$ & $774,800,000$ \\
\hline \multicolumn{6}{|c|}{ Data biaya operasional bulan Juli 2012} & & \\
\hline & & & & & & & \\
\hline & & \multicolumn{2}{|c|}{ Biaya / hari } & \multicolumn{2}{|c|}{ Biaya / bulan } & & \\
\hline \multicolumn{2}{|c|}{ Biaya bahan baku } & $\mathrm{Rp}$ & $1,500,000$ & $\mathrm{Rp}$ & $39,000,000$ & & \\
\hline \multicolumn{2}{|c|}{ Biaya filter } & - & & $\mathrm{Rp}$ & 200,000 & & \\
\hline & & \multicolumn{4}{|c|}{ Gaji / orang / bul biaya gaji/ bulan } & & \\
\hline \multicolumn{2}{|c|}{ Biaya tena ( 15 orang } & $\mathrm{Rp}$ & $1,450,000$ & $\mathrm{Rp}$ & $21,750,000$ & & \\
\hline Jumlah & & & & $\mathrm{Rp}$ & $60,950,000$ & & \\
\hline
\end{tabular}

Strategi keuangan yang di teliti melipuiti pengelolaan dan pengawasan catatan- catatan keuangan, perencanaan dan pengelolaan anggaran dalam mencapai tujuan memaksimalkan keuntungan pemilik perusahaan. Efektifitas pengelolaan oleh pemilik dalam dokumen rencana strateginya, jika tujuan bisnis adalah membangun skala besar usaha yang luas, meningkatkan market share dan jumlah konsumen, maka strategi keuangan dengan meningkatkan atau menetapkan profit margin yang tinggi, hanya menggunakan modal sendiri, dan memperbanyak aset tetap, mungkin tidak akan cocok. Untuk mendukung tujuan bisnis di atas akan lebih tepat di buat margin keuntungan yang tidak terlalu besar sehingga hanya cukup kompetitif di gunakan ulang karena keterbatasan pendanaan modal sendiri, dan menggunakan aset tetap melalui fasilitas sewa, bukan di miliki sendiri, untuk meminimalkan modal kerja yang di butuhkan.

Laporan arus kas ( cash flow ) adalah laporan yang merangkum kondisi kas, baik aliran kas masuk maupun aliran kas keluar pada suatu rentang waktu ( mingguan, bulanan, atau tahunan ). Laporan arus kas ini memberikan informasi terkait dengan perelaku penerimaan dan pengeluaran usaha. Laporan arus kas menggunakan dasar kas ( cash base ) sehingga pos - pos seperti depresiasi, amortisasi, dan acruals tidak di masukkan dalam laporan ini.

Laporan arus kas PT TIRTA MAMBERAMO yang di nilai mulai dari bulan agustus 2011 sampai dengan bulan juli 2012, menunjukan aliran kas yang sehat dan menunjukan keuntungan yang sangat signifikan .

Keuntungan yang didapatkan di karenakan belum mampu pembelian aktiva tetap dan, sumber daya manusia yang di pekerjakan masih dalam skala kecil kemudian pengeluaran untuk direct cost masih sangat kecil jika di bandingkan dengan produk penjualan yang di hasilkan sehingga dari analisis tersebut perusahaan mampu membiayai proses produksi tanpa melibatkan kreditur dari luar perusahaan untuk mendanai proses produksi PT TIRTA MAMBERAMO.

Jika di kaitkan dengan prospek bisnis ke depan untuk wilayah kota dan 
kabupaten sorong, kesimpulan peluang expansi sangat memungkinkan PT TIRTA MAMBERAMO untuk mengembangkan bisnis air minum kemasan dalam jumlah dan skala yang besar.

Untuk mempertahankan aliran kas yang telah di capai perusahaan perlu beberapa cara pengelolaan kas sehingga perusahaan tetap mempertahankan hasil hasil aliran kas yang telah di capai.

Usaha itu antara lain :

1. mempertahankan siklus konversi kas ( cash conversion )

Yaitu waktu yang di butuhkan untuk mengubah kas menjadi kas kembali, siklus ini di mulai dari kas awal yang di gunakan untuk membeli persediaan guna kegiatan produksi, kemudian diproses menjadi produk yang siap dijual, dilakukan penjualan dan berakhir di penagihan penjualan. Semakin cepat waktu yang di butuhkan untuk mengkonversi dari kas menjadi kas kembali, maka modal kerja yang di butuhkan akan semakin seikit.

2. Mengoptimalkan kebijakan manajemen kas ( cash management )

Yaitu menentukan jumlah kas optimal, misalnya menggunakan anggaran kas, untuk menghindari cash shortage dan investment opportunity cost.

3. Mengoptimalkan kebijakan inventory management ( manajemen investasi)

Yaitu semakin sedikit persediaan yang di miliki tentu akan semakin sedikit pula modal kerja yang di butuhkan namun terlalu sedikit sediaan, terdapat resiko tidak terlayaninya konsumen.

4. Mengoptimalkan

kebijakan manajemen piutang

Sedapat mungkin mengurangi besarnya piutang kepada konsumen. Jika terpaksa ada, pastilah jatuh tempo dalam pembayaran akan semakin pendek. Dan jika terlanjur memiliki piutang dalam jumlah yang signifikan, segera perbaiki manajemen perbaikannya.

5. Mengoptimalkan kebijakan manajemen utang .

Memperbaiki posisi (tawar ) perusahaan dengan creditor / supplier sehingga perusahaan mendapatkan fleksibilitas dalam pembayaran serta tempo pembayaran yang lebih lama jika kondisi tersebut terjadi, maka kebutuhan modal kerja dapat di tekan.

Melihat kondisi cash flow perusahaan air PT TIRTA MAMBERAMO , kesimpulan berkembang sangat terbuka luas dengan di tunjang koindisi demografis kota dan kabupaten sorong dan kabupaten kabupaten sekitarnya.

\section{KESIMPULAN DAN SARAN Kesimpulan}

1. Perusahaan mempunyai kesempatan untuk ekspansi yang di buktikan dari keuntungan yang di peroleh tiap bulannya.

2. Perusahaan di sarankan untuk menggunakan keuntungan itu untuk investasi aktifa tetap, menambah sumber daya manusia yang kompetensi, serta memperluas lokasi perusahaan.

3. Memperbaiki struktur organisasi untuk jangka panjang

4. Meningkatkan daerah pemasaran kewilayah - wilayah yang berada di luar daerah dan kabupaten sorong.

5. Hasil laporan cash flow perusahaan memberikan dampak untuk posisi keuangan untuk tahun - tahun yang akan dating. 


\section{Saran}

1. Bagi manajemen perusahaan ternyata laporan cash flow yang di hasilkan tiap bulannya berdampak signifikan terhadap proses kegiatan perusahaan.

2. Bagi manajemen perusahaan memperoleh kesempatan dan bahkan membuka diri untuk para investor .Mencari lokasi perusahaan yang lebih luas agar proses produksi dapat berjalan dengan lebih baik lagi.

3. Meningkatkan promoso mix marketing yang terdiri dari harga, produk, tempat, promosi, yang bias bersaing.

\section{DAFTAR PUSTAKA}

Nurmawan,S.Pd. 2009. Perhitungan laba/rugi suatu usahahttp://yandriana.files.wordpress.c om/2009/03/rugi-suatu-usaha.pdf. di akses pada tanggal 6 oktober 2012

Widy brawijaya, 11 januari 2012, klasifikasi biaya, file:// www.docstoc.com/docs/76562120/Ak untansi-Biaya-Klasifikasi-Biaya. di akses pada tanggal 11 oktober 2012

Admin, 29 april 2012, konsep dan klasifikasi

biaya,http://id.shvoong.com/busssiness -management/marketing/2180287-

definisi-atau-pengertian-biayapemasaran/\#ixzz27m5NjSEy. Di akses pada tanggal 11 oktober 2012

Andreas Viklund,2009,Pengertian dan penggolongan biaya, http//yandriana.files.wordpress.com/pe ngertian-dan-penggolonganbiaya.html. di akses pada tanggal 12 oktober 2012

J. fred Weston,1994, dasar - dasar manajemen keuangan jilid 1, edisi kesembilan, penerbit erlangga
Ikatan akutansi keuangan, 2007, standar akutansi keuangan, penerbit salemba empat 
Jurnal Noken 2 (2)1-14 2017 